\title{
PHYSICOCHEMICAL PROPERTIES OF JAMMUN SEED OIL
}

\section{P. ISSAC PRASAD ${ }^{1}$, K.M.V. RAVI TEJA ${ }^{2} \&$ K V. SAI GANESH ${ }^{* 3}$}

${ }^{1}$ Professor, Department of Mechanical Engineering, Koneru Lakshmaiah Educational Foundation, Green Fields, Vaddeswaram, Guntur 522502, Andhra Pradesh, India

${ }^{2}$ Assistant Professor, Department of Mechanical Engineering, Koneru Lakshmaiah Educational Foundation, Green Fields, Vaddeswaram, Guntur 522502, Andhra Pradesh, India

${ }^{3} P G$ Scholar, Department of Mechanical Engineering, Koneru Lakshmaiah Educational Foundation, Green Fields, Vaddeswaram, Guntur 522502, Andhra Pradesh, India

\begin{abstract}
In search of an alternative solution to the increasing in the demand of fuel and its depleting stock across the world, the continuous experiments on bio-oil with property measurement swere conducted,analysed and compared in this study.Theproperties Jamun seed oil of biodiesel were investigated. These seed oils are rich of conjugated fatty acids and variety of applications in food industry.Jammun seed oil is Biofuel, renewable and biodegradable and having similar properties to petro-diesel fuel. The study also revealed the oil properties compared to diesel. The physicochemical and physical parameters of the seed oil are analysed and the properties of seed oils are compared. The paper summarizes various oil properties like $\mathrm{pH}$ value, Flash point, fire point, redwood viscosity, acalorific value, carbon residue, cloud point, pour point, boiling point, aliphatic/aromatic compounds and hydrocarbons like Prelate and AlCl3tests
\end{abstract}

KEYWORDS: Bio-Oil, Oil Properties, Comparison with Diesel, Physiochemical Properties \& Jammun Seed Oils

Received: Feb 01, 2020; Accepted: Feb 14, 2020; Published: Mar 07, 2020; Paper Id.: IJMPERDAPR2020135 